UDK $577.1: 61$

ISSN 1452-8258

\title{
GENETIC VARIABILITY IN SODIUM-GLUCOSE COTRANSPORTER 2 INFLUENCES GLYCEMIC CONTROL AND RISK FOR DIABETIC RETINOPATHY IN TYPE 2 DIABETES PATIENTS
}

\author{
GENETSKA VARIJABILNOST U NATRIJUM-GLUKOZNOM TRANSPORTERU 2 UTIČE \\ NA KONTROLU GLIKEMIJE I NA RIZIK ZA RAZVOJ DIJABETIČKE RETINOPATIJE \\ KOD PACIJENATA SA DIJABETESOM TIPA 2
}

\author{
Jasna Klen 1,a, Katja Goričar², Vita Dolžan ${ }^{2}$ \\ ${ }^{1}$ General Hospital Trbovlje, Trbovlje, Slovenia \\ ${ }^{2}$ Pharmacogenetics Laboratory, Institute of Biochemistry, Faculty of Medicine, \\ University of Ljubljana, Ljubljana, Slovenia \\ ${ }^{a}$ Present address: University Medical Centre Ljubljana, Division of Surgery, \\ Department of Abdominal Surgery, Ljubliana, Slovenia
}

\begin{abstract}
Summary
Background: Gluconeogenesis and renal glucose excretion in kidneys both play an important role in glucose homeostasis. Sodium-glucose cotransporter (SGLT2), coded by the SLC5A2 gene is responsible for reabsorption up to $99 \%$ of the filtered glucose in proximal tubules. SLC5A2 genetic polymorphisms were suggested to influence glucose homeostasis. We investigated if common SLC5A2 rs9934336 polymorphism influences glycemic control and risk for macro or microvascular complications in Slovenian type 2 diabetes (T2D) patients.

Methods: All 181 clinically well characterized T2D patients were genotyped for SLC5A2 rs9934336 G>A polymorphism. Associations with glycemic control and T2D complications were assessed with nonparametric tests and logistic regression.

Results: SLC5A2 rs9934336 was significantly associated with increased fasting blood glucose levels $(P<0.001)$ and $\mathrm{HbA} 1 \mathrm{c}$ levels under the dominant genetic model $(P=0.030)$. After adjustment for T2D duration, significantly higher risk for diabetic retinopathy was present in carriers of at least one polymorphic SLC5A2 rs9934336 A allele compared to non-carriers $(\mathrm{OR}=7.62 ; 95 \% \mathrm{Cl}=1.65$ 35.28; $\mathrm{P}=0.009$ ).
\end{abstract}

\section{Kratak sadržaj}

Uvod: Glukoneogeneza i izlučivanje glukoze u bubrezima imaju važnu ulogu u homeostazi glukoze. Natrijum-glukozni kotransporter (SGLT2), kodiran od strane gena SLC5A2, odgovoran je za reapsorpciju do $99 \%$ filtrirane glukoze u proksimalnim tubulima. Predloženo je da genetski polimorfizmi SLC5A2 utiču na homeostazu glukoze. Ispitali smo, da li učestali polimorfizam SLC5A2 rs9934336 utiče na glikemičku kontrolu i na rizik za makro i mikrovaskularne komplikacije kod pacijenata iz Slovenije sa dijabetesom tipa 2 (T2D).

Metode: Svih 181 klinički dobro okarakterisanih pacijenata sa T2D je genotipizirano na polimorfizam SLC5A2 rs9934336 G>A. Povezanost sa kontrolom glikemije i komplikacijama T2D ispitivana je neparametrijskim testovima i logističkom regresijom.

Rezultati: SLC5A2 rs9934336 je značajno povezan sa povecanim nivoima glukoze u krvi natašte $(P<0,001)$ i nivoima $\mathrm{HbA} 1 \mathrm{c}$ pod dominantnim genetskim modelom ( $P$ $=0,030)$. Nakon uzimanja u obzir trajanje T2D, značajno veci rizik za dijabetičku retinopatiju bio je prisutan kod nosilaca najmanje jednog polimorfnog alela SLC5A2 rs9934336 A u odnosu na pacijente koji nisu nosioci (OR $=7,62 ; 95 \% \mathrm{Cl}=1,65-35,28 ; \mathrm{P}=0,009)$.

List of abbreviations: $\mathrm{Cl}$, confidence interval; $\mathrm{HbA} 1 \mathrm{c}$, glycated hemoglobin; ICD, ischemic cerebral disease; MI, myocardial infarction; $N$, number of patients; $O R$, odds ratio; PAOD, peripheral arterial occlusive disease; SGLT2, sodium-glucose cotransporter; SNP, single nucleotide polymorphism; T2D, type 2 diabetes; TmG, transport maximum for glucose reabsorption

\footnotetext{
Address for correspondence:

Vita Dolžan, PhD, MD

Pharmacogenetics Laboratory, Institute of Biochemistry, Faculty of Medicine, University of Ljubljana, Vrazov trg 2, 1000 Ljubljana, Slovenia tel: +38615437670, fax: +38615437641 e-mail: vita.dolzan@mf.uni-lj.si
} 
Conclusions: Our pilot study suggests an important role of SLC5A2 polymorphisms in the physiologic process of glucose reabsorption in kidneys in T2D patients. This is also the first report on the association between SLC5A2 polymorphism and diabetic retinopathy.

Keywords: diabetes type 2, SLC5A2; SGLT2, genetic polymorphism, retinopathy

\section{Introduction}

Type 2 diabetes (T2D) results from defects in insulin secretion, deficiency in insulin signaling and/or insulin resistance that may contribute to chronic hyperglycemia (1). Micro and macrovascular complications are common long term complications of T2D that may be prevented or at least delayed with rapid diagnosis and proper antihyperglycemic therapy (2).

Kidneys have an important role in lowering glucose plasma levels as they filter around 180 liters of plasma every day, first by secreting approximately 160-180 grams of glucose per day and then by reabsorbing virtually all this glucose in normoglycemic subjects. Two sodium-glucose transporters (SGLT) belonging to the solute carrier family 5 (SLC5) play an important role in glucose reabsorption in the kidney. From the renal ultrafiltrate approximately $90 \%$ of glucose is reabsorbed in insulin independent process by SGLT2 (SLC5A2) in segments 1 and 2, while 10\% is reabsorbed by SGLT1 in segment 3 (SLC5A1) of the proximal tubule (3). As these transporters have a transport maximum for glucose reabsorption (TmG) from glomerular filtrate, maximal glucose reabsorption capacity (around $10 \mathrm{mmol} / \mathrm{L}$ ) may be exceeded in T2D patients with hyperglycemia. The excess glucose which cannot be reabsorbed is excreted in the urine, leading to glucosuria $(4,5)$.

The increased capacity of the kidney to reabsorb glucose and increased TmG occur due to increased expression of SGLT2 in T2D patients with chronic hyperglycemia and contribute to the maintenance of hyperglycemia $(5,6)$. SGLT2 inhibition has been recognized as a novel and safe approach to lowering high glucose levels in T2D and several SGLT2 inhibitors were developed and tested in clinical trials $(7,8)$. In addition to their excellent high blood glucose lowering potential without the risk of hypoglycemias, they also showed both cardioprotective (7) and renoprotective effect $(9,10)$. Further studies are needed to demonstrate if SGLT2 inhibitors have a protective effect against other late complications of T2D.

Several studies, including our own have previously shown that genetic factors play an important role in the risk of development late T2D complications $(11,12)$. Genetic variability was also identified in the SLC5A2 gene coding for SGLT2. Severe, but rare SLC5A2 mutations were associated with familial
Zaključak: Naša pilot-studija ukazuje na važnu ulogu polimorfizama SLC5A2 u fiziološkom procesu reapsorpcije glukoze u bubrezima kod pacijenata sa T2D. Ovo je takođe prva studija o povezanosti polimorfizma SLC5A2 i dijabetičke retinopatije.

Ključne reči: dijabetes tip 2, SLC5A2, SGLT2, genetički polimorfizam, retinopatija

renal glucosuria, a benign condition with normal blood glucose (13). Initial studies of common functional polymorphisms identified in SLC5A2 suggested their influence on glucose homeostasis in non-diabetic subjects (14) however a recent study on T2D patients observed no significant effect of SLC5A2 genetic variability on patients' metabolic traits or their response to treatment with empagliflozin (15).

The aim of our study was to investigate if common polymorphism SLC5A2 rs9934336 influences blood glucose levels and risk for macro and microvascular complications in Slovenian Type 2 diabetes patients even in the absence of treatment with SGLT2 inhibitors.

\section{Materials and Methods}

\section{Patients}

Our retrospective study included T2D patients aged between 18 to 75 years when they came for regular visits at the outpatient clinic at General Hospital Trbovlje. Most of the patients were treated with sulphonylurea either in monotherapy or in combination with metformin. Patients with end-stage renal failure due to diabetic nephropathy were mostly treated with insulin. Exclusion criteria were diabetes type 1, gestational diabetes, other types of diabetes, active cancer, heart failure New York Heart Association (NYHA) 3-4, co-treatment with corticosteroids or estrogens, conditions that can cause hyperglycaemia, addiction to alcohol or illegal drugs and dementia or severe psychiatric disorders as described in detail in our previous study (11). Information on the history of diabetes, presence of arterial hypertension, hyperlipidemia and chronic diabetic complications, smoking status and other medications was obtained from the medical records. At least once per year plasma lipid levels, urea and creatinine and urine albumin and albumin/creatinine ratio were determined. Kidney function was assessed in line with the revised chronic kidney disease classification (16). Albuminuria was classified as normal $(<20 \mathrm{mg} / \mathrm{L})$, moderately increased albuminuria $(20-200 \mathrm{mg} / \mathrm{L}$, formerly known as microalbuminuria) and severely increased albuminuria (>200 mg/L, formerly known as macroalbuminuria). Estimated glomerular filtration was calculated according to the Modification of Diet in Renal Disease Study (MDRD) (17). Once per year patients were referred to consulting ophthalmologist 
for screening for diabetic retinopathy. Echosonography and exercise stress test (cycloergometry) were performed at the first visit and also at any complaints suggestive for ischemic heart disease.

The study was approved by the National Ethics Committee and conducted in accordance with the Declaration of Helsinki. Written informed consent was obtained from all subjects.

\section{SNP selection, DNA isolation and genotyping}

SLC5A2 rs9934336 (c.127-121G >A, intronic single nucleotide polymorphism (SNP)) was selected based on previously published literature (14). We also checked for other common putatively functional nonintronic SNPs in SLC5A2 using SNP database (18) but no other candidate SNP was found.

Genomic DNA was extracted from whole-blood frozen samples collected at the inclusion in the study using the Qiagen FlexiGene Kit (Qiagen, Hilden, Germany) according to the manufacturer's instructions.

Genotyping of SLC5A2 rs9934336 was carried out using a fluorescence-based competitive allelespecific (KASPar) assay according to the manufacturer's instructions (LGC Genomics, UK). Genotyping was performed blind to any clinical data and was randomly repeated in $15 \%$ of samples. Genotyping quality control criteria were 100\% duplicate call rate and 95\% SNP-wise call rate. Duplicate call rate and SNPwise call rate were $100 \%$.

\section{Statistical analysis}

Median with interquartile range and frequencies were used to describe continuous and categorical variables, respectively. Chi-square test was used to assess potential deviation from Hardy-Weinberg equilibrium. Nonparametric Kruskal-Wallis and MannWhitney tests were used to evaluate the association with basal glucose and $\mathrm{HbA} 1 \mathrm{c}$, while logistic regression was used to assess risk for macro and microvascular complications. All statistical analyses were performed using IBM SPSS Statistics 19.0 (IBM Corporation, Armonk, NY, USA). All statistical tests were two sided. To lower the chance of false positive findings, Benjamini-Hochberg false discovery rate was used to account for multiple comparisons (19). The level of statistical significance was set at 0.004 and $P$ values between 0.004 and 0.050 were considered as nominally significant.

Based on measurements from previous studies, we could detect differences between groups of $\pm 0.42 \%$ for glycated hemoglobin ( $\mathrm{HbA} 1 \mathrm{c}$ ) or \pm 0.85 $\mathrm{mmol} / \mathrm{I}$ for fasting glucose with $80 \%$ power based on our sample size. For macrovascular complications, based on our sample size and SLC5A2 rs9934336 minor allele frequency, we could detect odds ratios 0.23 or 2.69 with $80 \%$ power. For microvascular complications, based on our sample size and SLC5A2 rs9934336 minor allele frequency, we could detect odds ratios 0.18 or 2.97 with $80 \%$ power.

\section{Results}

\section{Patients' characteristics}

Our study included 181 T2D patients, 105 (58.0\%) male and 76 (42\%) female, with median age 64 (58.5-70.5) years. Median T2D duration at the inclusion in the study was $11(6-17)$ years.

Most of the patients were treated with sulphonylurea, either in monotherapy $(21 ; 13.5 \%)$ or in combination with metformin (135; 86.5\%). Among 25 hemodialysis patients with end-stage renal failure due to diabetic nephropathy, 20 (80\%) were on insulin treatment, $1(4 \%)$ patient was treated with sulphonylurea in monotherapy, while others (16\%) were on diet. Fasting glucose levels were available for 104 patients, and 94 (90.4\%) had values above $6.1 \mathrm{mmol} / \mathrm{L}$. Median fasting glucose level was 7.5 (6.7-8.7) $\mathrm{mmol} / \mathrm{L}$. Still, most of the patients had relatively normal blood glucose control with median $\mathrm{HbA} 1 \mathrm{c} 6.8 \%$ (6.3-7.6). Patients also had well controlled blood pressure and plasma lipid levels (Table I). No significant differences were observed with regards to the laboratory parameters between males and females, except for the slightly higher HDL-cholesterol levels in females $(P=0.008)$ (data not shown). Regarding kidney function, 51 patients had stage 1, 105 patients had stage

Table I Patients characteristics.

\begin{tabular}{|l|c|}
\hline & T2D patients $(\mathrm{N}=181)$ \\
\hline Male gender ${ }^{a}$ & $105(58.0)$ \\
\hline Age (years) & $11.0(6.0-17.0)$ \\
\hline Duration of T2D (years) & $6.9(6.3-7.6)[52(45-60)]$ \\
\hline HbA1c (\%), mmol/mol & $7.5(6.7-8.7)$ \\
\hline Fasting blood glucose (mmol/L) & $30.0(28.0-33.3)$ \\
\hline BMI (kg/m ${ }^{2}$ ) & $135.0(130.0-145.0)$ \\
\hline Blood pressure systolic (mmHg) & $80.0(70.0-80.0)$ \\
\hline Blood pressure diastolic (mmHg) & $4.2(3.5-5.0)$ \\
\hline Total cholesterol (mmol/L) & $2.4(1.9-3.1)$ \\
\hline LDL-cholesterol (mmol/L) & $1.1(1.0-1.4)$ \\
\hline HDL-cholesterol (mmol/L) & $1.6(1.2-2.4)$ \\
\hline TAG (mmol/L) &
\end{tabular}

Data are shown as median (25\%-75\%), except for: ${ }^{a} \mathrm{~N}(\%)$.

bata available for 104 patients. 
2 or 3 chronic kidney disease, and 25 patients had end-stage (stage 5) renal failure due to diabetic nephropathy and required hemodialysis.

\section{Genotyping analysis}

SLC5A2 rs9934336 genotype distribution was as follows: 101 (55.8\%) of patients were homozygous for normal GG genotype, 67 (37.0\%) were GA heterozygous and 13 (7.2\%) were homozygous for polymorphic AA genotype. Minor allele frequency was 0.257 . The distributions was in agreement with Hardy-Weinberg equilibrium $(P=0.682)$. Genotype frequencies were in HWE also in all subgroups with late complications (data not shown).

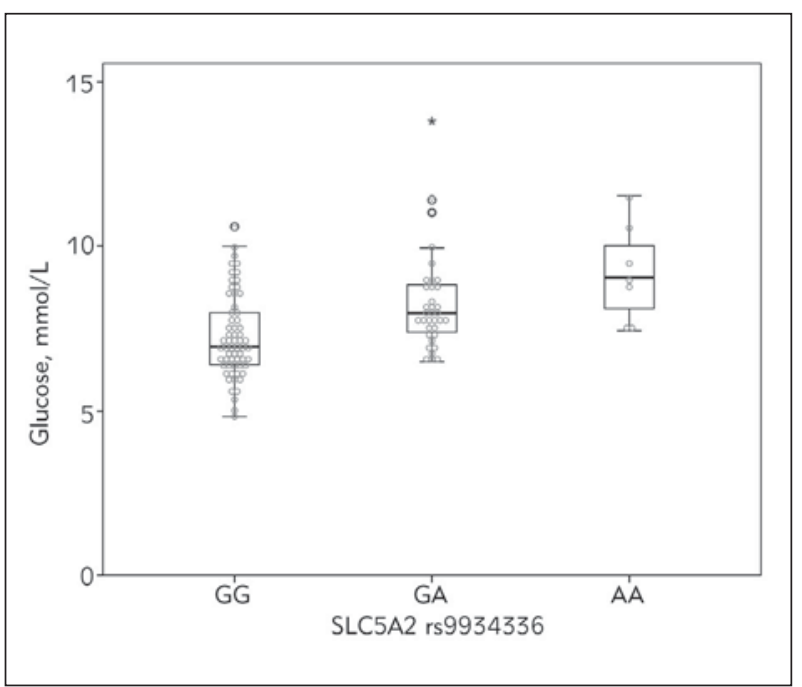

Figure 1 Fasting blood glucose levels in T2D patients according to SLC5A2 rs9934336 genotype.

Table II The association of SLC5A2 rs9934336 genotype with fasting glucose and $\mathrm{HbA} 1 \mathrm{c}$ levels in T2D patients.

\begin{tabular}{|l|c|c|}
\hline Genotype & $\begin{array}{c}\text { Fasting glucose } \\
(\mathrm{mmol} / \mathrm{L})^{\mathrm{a}}\end{array}$ & HbA1c (\%) \\
\hline Gedian (25\%-75\%) & Median (25\%-75\%) \\
\hline GA & $6.96(6.40-7.99)$ & $6.7(6.3-7.3)$ \\
\hline AA & $9.96(7.31-8.83)$ & $6.9(6.4-7.7)$ \\
\hline Pb & $<0.001$ & $7.1(6.7-8.2)$ \\
\hline GA+AA & $8.04(7.43-8.92)$ & $7.0(6.4-7.7)$ \\
\hline Pc & $<0.001$ & 0.030 \\
\hline
\end{tabular}

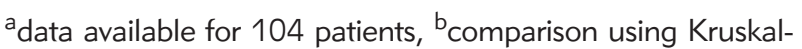
Wallis test, 'comparison using Mann-Whitney test
Association with fasting glucose and HbA1c levels

SLC5A2 rs9934336 was significantly associated with increased fasting blood glucose levels both in additive and dominant genetic models (both $P<0.001)$. Fasting glucose levels were 6.96 (6.40$7.99) \mathrm{mmol} / \mathrm{L}$ for patients with normal GG genotype, 7.96 (7.31-8.83) mmol/L for patients with GA genotype and 9.04 (7.43-10.51) mmol/L for polymorphic AA genotype (Figure 1). The association of rs9934336 genotype with slightly higher HbA1c levels was nominally significant only under the dominant genetic model $(P=0.030)$ (Table II).

\section{Late complications}

Macrovascular complications were observed in 46 (25.4\%) patients: 10 had peripheral arterial occlusive disease (PAOD), 16 ischemic cerebral disease (ICD) and 32 myocardial infarction (MI). Microvascular complications were observed in 34 (18.8\%) patients: 25 (13.8\%) patients had end stage kidney failure due to diabetic nephropathy, 13 (7.2\%) neuropathy and $15(8.3 \%)$ retinopathy.

HbA1c was not significantly associated with risk for macrovascular complications (OR=0.75; 95\% $\mathrm{Cl}=0.53-1.06$; $\mathrm{P}=0.102)$, but tended to be associated with slightly decreased risk for microvascular complications $(\mathrm{OR}=0.67 ; 95 \% \mathrm{Cl}=0.45-0.99$; $\mathrm{P}=0.042$ ). In the subgroup with available fasting blood glucose data, median blood glucose level was not significantly associated with risk for macrovascular complications $(\mathrm{OR}=0.81 ; 95 \% \mathrm{Cl}=0.56-1.18$; $\mathrm{P}=0.276)$ or microvascular complications $(\mathrm{OR}=0.57$; 95\% Cl=0.26-1.22; $\mathrm{P}=0.147$ ).

In logistic regression analysis, longer duration of T2D and lower HDL cholesterol levels were the most important clinical risk factors increasing the odds for macrovascular complications $(\mathrm{OR}=1.08 ; 95 \% \mathrm{Cl}=$ 1.03-1.12; $\mathrm{P}=0.001$ and $\mathrm{OR}=0.20 ; 95 \% \mathrm{Cl}=$ $0.06-0.64 ; \mathrm{P}=0.007$, respectively). The most important clinical risk factor increasing the odds for microvascular complications was longer duration of T2D $(O R=1.12 ; 95 \% \mathrm{Cl}=1.07-1.17 ; \mathrm{P}<0.001)$. These parameters were therefore used in for adjustment in multivariable logistic regression.

Retinopathy was the only late T2D complication associated with SLC5A2 polymorphism after adjustment for T2D duration (Table III). Carriers of at least one polymorphic SLC5A2 rs9934336 A allele had nominally significantly higher risk for diabetic retinopathy than non-carriers $(\mathrm{OR}=7.62 ; 95 \% \mathrm{Cl}=1.65-$ 35.28; $P=0.009$ ). 
Table III The association of SLC5A2 rs9934336 with the risk for macrovascular and microvascular complications in type 2 diabetes patients (adjusted for clinical parameters).

\begin{tabular}{|c|c|c|c|c|c|}
\hline Complication & & Genotype & & & \\
\hline & & GG & GA & $\overline{A A}$ & $\mathrm{GA}+\mathrm{AA}$ \\
\hline \multirow[t]{3}{*}{ Macrovascular } & $\mathrm{N}(\%)$ & $28(27.7)$ & $14(20.9)$ & $4(30.8)$ & $18(22.5)$ \\
\hline & OR $(95 \% \mathrm{Cl})$ & Reference & $0.71(0.32-1.55)$ & $0.95(0.26-3.51)$ & $0.75(0.36-1.55)$ \\
\hline & $P$ & & 0.384 & 0.934 & 0.436 \\
\hline \multirow[t]{3}{*}{ PAOD } & $\mathrm{N}(\%)$ & $6(5.9)$ & $4(6.0)$ & $0(0.0)$ & $4(5.0)$ \\
\hline & OR $(95 \% \mathrm{Cl})$ & Reference & $1.01(0.26-3.89)$ & / & $0.81(0.21-3.07)$ \\
\hline & $P$ & & 0.987 & I & 0.752 \\
\hline \multirow[t]{3}{*}{$I C D$} & $\mathrm{~N}(\%)$ & 9 (8.9) & $5(7.5)$ & $2(15.4)$ & $7(8.8)$ \\
\hline & OR $(95 \% \mathrm{Cl})$ & Reference & $0.87(0.27-2.78)$ & $1.65(0.31-8.87)$ & $1.01(0.35-2.90)$ \\
\hline & $P$ & & 0.811 & 0.557 & 0.993 \\
\hline \multirow[t]{3}{*}{ MI } & $\mathrm{N}(\%)$ & $20(19.8)$ & $10(14.9)$ & $2(15.4)$ & $12(15.0)$ \\
\hline & OR $(95 \% \mathrm{Cl})$ & Reference & $0.78(0.32-1.89)$ & $0.63(0.12-3.31)$ & $0.75(0.33-1.73)$ \\
\hline & $P$ & & 0.579 & 0.587 & 0.500 \\
\hline \multirow[t]{3}{*}{ Microvascular } & $\mathrm{N}(\%)$ & $19(18.8)$ & $13(19.4)$ & $2(15.4)$ & $15(18.8)$ \\
\hline & OR $(95 \% \mathrm{Cl})$ & Reference & $1.25(0.53-2.95)$ & $0.75(0.14-4.05)$ & $1.15(0.51-2.61)$ \\
\hline & $P$ & & 0.606 & 0.741 & 0.733 \\
\hline \multirow[t]{3}{*}{ End-stage kidney } & $N(\%)$ & $14(13.9)$ & $9(13.4)$ & $2(15.4)$ & $11(13.8)$ \\
\hline & OR $(95 \% \mathrm{Cl})$ & Reference & $1.24(0.45-3.40)$ & $1.21(0.21-7.04)$ & $1.23(0.47-3.20)$ \\
\hline & $\mathrm{P}$ & & 0.677 & 0.833 & 0.666 \\
\hline \multirow[t]{3}{*}{ Retinopathy } & $\mathrm{N}(\%)$ & $5(5.0)$ & $8(11.9)$ & $2(15.4)$ & $10(12.5)$ \\
\hline & OR $(95 \% \mathrm{Cl})$ & Reference & $7.39(1.53-35.65)$ & $8.83(0.92-84.57)$ & $7.62(1.65-35.28)$ \\
\hline & $P$ & & 0.013 & 0.059 & 0.009 \\
\hline Neuropathy & $\mathrm{N}(\%)$ & $6(5.9)$ & $5(7.6)$ & $2(15.4)$ & $7(8.9)$ \\
\hline \multirow{2}{*}{+2} & OR $(95 \% \mathrm{Cl})$ & Reference & $1.56(0.44-5.58)$ & $3.06(0.52-17.90)$ & $1.82(0.56-5.90)$ \\
\hline & $\mathrm{P}$ & & 0.491 & 0.214 & 0.317 \\
\hline
\end{tabular}

$P$ values are adjusted for T2D duration and HDL cholesterol for macrovascular complications and adjusted for T2D duration for microvascular complications.

$\mathrm{Cl}$, confidence interval; ICD, ischemic cerebral disease; MI, myocardial infarction; N, number of patients; OR, odds ratio; PAOD, peripheral arterial occlusive disease

\section{Discussion}

In the present study we investigated the role of genetic variability in the principal glucose transporter SGLT2 on glycaemia and long term outcomes in T2D patients not treated with SGLT2 inhibitors. We have shown that genetic variability of SLC $5 A 2$ gene coding for SGLT2 influences both fasting glucose levels and $\mathrm{HbA1c}$. In addition we have observed an association of SLC5A2 rs9934336 polymorphism with the risk for diabetic retinopathy, although no associations were observed with other microvascular or macrovascular late complications of T2D.

The most important finding of our study was that SLC5A2 rs9934336 polymorphism significantly influenced fasting blood glucose levels in T2D patients. We even observed a gene dose effect, with the carriers of one polymorphic SLC5A2 rs9934336 A allele having higher median fasting glucose levels than non-carriers, while carriers of two polymorphic had the highest fasting blood glucose levels. The effect of SLC5A2 rs9934336 genotypes on HbA1c levels was less pronounced, however significant under the dominant genetic model. Modest association of SLC5A2 rs9934336 polymorphism with glucose concentrations during oral glucose tolerance test was also observed in a cohort of German Sorb nondiabetic individuals with either normal glucose tolerance, impaired fasting glucose or impaired glucose tolerance. However in this particular group, carriers of polymorphic rs9934336 AA genotype had reduced glucose concentrations 30-min after oral glucose load (14). Another German study showed no association of this polymorphism with fasting plasma glucose levels, $\mathrm{HbA} 1 \mathrm{c}$ or the glucose concentrations during oral glucose tolerance test neither in individuals with increased risk for T2D nor in T2D patients treated with empagliflozin (15). Regarding the small number 
of studies and the discrepant results, the role of SLC5A2 rs9934336 polymorphism in glucose homeostasis remains to be determined. Furthermore, functional studies should be performed to elucidate the role of this polymorphism in glucose transport.

To our knowledge, so far only one study reported that common genetic variants in the SLC5A2 gene did not affect diabetes-related metabolic traits such as body fat or systolic blood pressure which may represent a risk for development of late T2D complications (15). However in our study we observed an interesting association of SLC5A2 rs9934336 polymorphism and the risk for development of diabetic retinopathy, but no other associations with either other microvascular or macrovascular late complications of T2D.

Diabetic retinopathy is most common late complication of T2D that significantly decreases patient's quality of life. Although the mechanisms underlying these conditions have been extensively studied, they remain unknown $(20,21)$. Animal model studies showed that in addition to expression in renal proximal tubular cells and other tissues (22) SGLT2 may be also expressed in bovine retinal pericytes (23). Among other important physiological functions, pericytes in the retina participate in microcirculation control and microvessel protection (23).

Pericytes play an important role in the development of diabetic retinopathy as pericyte swelling and loss was shown to occur in the early stage of diabetic retinopathy and leads to microaneurysm formation in the retina $(24,25)$.

It has been suggested that SGLT2 in retinal pericytes may have role of glucose sensor that controls cellular tone in response to changes in extracellular glucose concentrations (26). These findings may support the biological plausibility of our observations that genetic variability of SGLT2 may play a role in the development of diabetic retinopathy. It has been also show that glucose entry into pericytes increased twofold under hyperglycemia conditions (26). Such alterations in glucose supply could potentially change retinal energy metabolism and therefor result in complications (27).

Excessive SGLT2 mediated entry of glucose and sodium during high glucose conditions resulted in functional and morphological changes in retinal peri- cytes, but this effect was attenuated by nonselective SGLT inhibitor phlorizin (26). As the use of SGLT2 inhibitors is rapidly increasing in the treatment of T2D patients, their potential protective effect regarding the development of diabetic retinopathy through direct actions on retinal pericytes needs to be further investigated in clinical studies.

In conclusion, our pilot study suggests an important role of SLC5A2 polymorphisms in the physiologic process of glucose reabsorption in kidneys in T2D patients. Furthermore, we report for the first time a biologically plausible association between SLC5A2 polymorphism and diabetic retinopathy. Further studies are needed to investigate if genetic variability of SGLT2 transporters influences treatment outcome with the novel class of antidiabetic drugs that inhibit SGLT2.

Acknowledgements. We wish to acknowledge the clinical nurse Mrs. Nevenka Kirič for her support with clinical part of the study and Mrs. Savica Soldat, BSc for her expert technical assistance.

The preliminary data of this study were presented by Klen et al. as conference abstracts published in the American Diabetes Association's 76th Scientific Sessions Abstract Book (http://diabetes.diabetesjournals.org/content/diabetes/65/Supplement 1/A595. full.pdf). The preliminary data were also accepted for short presentation at the 41st FEBS Congress, Molecular and Systems Biology for a Better Life, Ephesus/ Kuşadasi, Turkey, September 3 8, 2016. Although the congress was canceled, the abstract was published in the FEBS Journal, Volume 283 Supplement 1, September 2016 (https://febs.onlinelibrary.wiley. com/doi/epdf/10.1111/febs.13805).

Funding. This work was supported by the Slovenian Research Agency [grant number P1-0170].

Disclosure. Prof. Dolzan reports grant P1-0170 from Slovenian Research Agency; other authors have nothing to disclose.

\section{Conflict of interest statement}

The authors stated that they have no conflicts of interest regarding the publication of this article. 


\section{References}

1. Samuel VT, Shulman GI. Mechanisms for insulin resistance: common threads and missing links. Cell 2012; 148: 852-71.

2. Matheus AS, Tannus LR, Cobas RA, Palma CC, Negrato CA, Gomes MB. Impact of diabetes on cardiovascular disease: an update. International journal of hypertension 2013; 2013: 653789.

3. Wright EM, Loo DD, Hirayama BA. Biology of human sodium glucose transporters. Physiological reviews 2011; 91: 733-94.

4. Dardi I, Kouvatsos T, Jabbour SA. SGLT2 inhibitors. Biochemical pharmacology 2016; 101: 27-39.

5. Jabbour SA. SGLT2 inhibitors to control glycemia in type 2 diabetes mellitus: a new approach to an old problem. Postgraduate medicine 2014; 126: 111-7.

6. DeFronzo RA, Davidson JA, Del Prato S. The role of the kidneys in glucose homeostasis: a new path towards normalizing glycaemia. Diabetes, obesity \& metabolism 2012; 14: 5-14.

7. Zinman B, Wanner C, Lachin JM, Fitchett D, Bluhmki E, Hantel S, et al. Empagliflozin, Cardiovascular Outcomes, and Mortality in Type 2 Diabetes. The New England journal of medicine 2015; 373: 2117-28.

8. Cefalu WT, Leiter LA, Yoon KH, Arias P, Niskanen L, Xie $\mathrm{J}$, et al. Efficacy and safety of canagliflozin versus glimepiride in patients with type 2 diabetes inadequately controlled with metformin (CANTATA-SU): 52 week results from a randomised, double-blind, phase 3 noninferiority trial. Lancet 2013; 382: 941-50.

9. Wanner C, Inzucchi SE, Lachin JM, Fitchett D, von Eynatten $M$, Mattheus $M$, et al. Empagliflozin and Progression of Kidney Disease in Type 2 Diabetes. The New England journal of medicine 2016; 375: 323-34.

10. Heerspink HJL, Kosiborod M, Inzucchi SE, Cherney DZI Renoprotective effects of sodium-glucose cotransporter-2 inhibitors. Kidney international 2018; 94: 26-39.

11. Klen J, Goricar K, Janez A, Dolzan V. NLRP3 Inflammasome Polymorphism and Macrovascular Complications in Type 2 Diabetes Patients. Journal of diabetes research 2015; 2015: 616747.

12. Klen J, Goricar K, Janez A, Dolzan V. Common polymorphisms in antioxidant genes are associated with diabetic nephropathy in Type 2 diabetes patients. Personalized medicine 2015; 12: 187-98.

13. Santer R, Calado J. Familial renal glucosuria and SGLT2: from a mendelian trait to a therapeutic target. Clinical journal of the American Society of Nephrology: CJASN 2010; 5: 133-41.

14. Enigk U, Breitfeld J, Schleinitz D, Dietrich K, Halbritter $\mathrm{J}$, Fischer-Rosinsky A, et al. Role of genetic variation in the human sodium-glucose cotransporter 2 gene (SGLT2) in glucose homeostasis. Pharmacogenomics 2011; 12: 1119-26.

15. Zimdahl $H$, Haupt $A$, Brendel $M$, Bour L, Machicao $F$ Salsali $A$, et al. Influence of common polymorphisms in the SLC5A2 gene on metabolic traits in subjects at increased risk of diabetes and on response to empagliflozin treatment in patients with diabetes. Pharmacogenetics and genomics 2017; 27: 135-42.

16. Levey AS, Eckardt KU, Tsukamoto Y, Levin A, Coresh J, Rossert J, et al. Definition and classification of chronic kidney disease: a position statement from Kidney Disease: Improving Global Outcomes (KDIGO). Kidney Int 2005; 67: 2089-100.

17. Levey AS, Bosch JP, Lewis JB, Greene T, Rogers N, Roth $D$. A more accurate method to estimate glomerular filtration rate from serum creatinine: a new prediction equation. Modification of Diet in Renal Disease Study Group. Ann Intern Med 1999; 130: 461-70.

18. Sherry ST, Ward MH, Kholodov M, Baker J, Phan L, Smigielski EM, et al. dbSNP: the NCBI database of genetic variation. Nucleic Acids Res 2001; 29: 308-11.

19. Rao N, Jain A, Goyale A, Persaud JW, Al-Musalhi K, Nair DR. Lipoprotein $X$ in autoimmune liver disease causing interference in routine and specialist biochemical investigations. Clinical Lipidology 2017; 12: 8-13.

20. Ola MS, Nawaz MI, Siddiquei MM, Al-Amro S, Abu El-Asrar AM. Recent advances in understanding the biochemical and molecular mechanism of diabetic retinopathy. Journal of diabetes and its complications 2012; 26: 56-64.

21. Ng ZX, Kuppusamy UR, Tajunisah I, Fong KC, Chua KH. Investigation of SLC2A1 26177A/G gene polymorphism via high resolution melting curve analysis in Malaysian patients with diabetic retinopathy. Journal of diabetes and its complications 2012; 26: 388-92.

22. Chen J, Williams S, Ho S, Loraine H, Hagan D, Whaley $J M$, et al. Quantitative PCR tissue expression profiling of the human SGLT2 gene and related family members. Diabetes therapy : research, treatment and education of diabetes and related disorders 2010; 1: 57-92.

23. Wakisaka $M$, Nagao T. Sodium glucose cotransporter 2 in mesangial cells and retinal pericytes and its implications for diabetic nephropathy and retinopathy. Glycobiology 2017.

24. von Tell D, Armulik A, Betsholtz C. Pericytes and vascular stability. Experimental cell research 2006; 312: 623-9.

25. Armulik A, Abramsson A, Betsholtz C. Endothelial/pericyte interactions. Circulation research 2005; 97: 512-23.

26. Wakisaka M, Nagao T, Yoshinari M. Sodium Glucose Cotransporter 2 (SGLT2) Plays as a Physiological Glucose Sensor and Regulates Cellular Contractility in Rat Mesangial Cells. PloS one 2016; 11: e0151585.

27. Sanchez-Chavez G, Pena-Rangel MT, Riesgo-Escovar JR, Martinez-Martinez A, Salceda R. Insulin stimulated-glucose transporter Glut 4 is expressed in the retina. PloS one 2012; 7: e52959. 